It is interesting to see that Lord and Smith (Tables 3 and 4) report that chalk of the same zone and in the same cutting have significantly different $N$ values. Experience would indicate that such rapid changes in $N$ value could not occur unless either a change in zone occurred or there was a marked difference in discontinuity openings. Perhaps some qualification of the chalk grading is therefore required in this instance.

Certainly one cannot use $N$ values in isolation, but there are circumstances, both physical and economic, in which visual inspection is restricted. In these circumstances, the fact remains that $N$ values are used, and although they can be difficult to interpret and can be misused, this is not to say that they are of no use. Of course only if some visual inspection of the chalk on a site has been made can valid interpretations of $N$ values be made. The correlation presented by Dennehy is therefore important in that it shows that low $N$ values do not necessarily mean poor grade chalk.

\title{
REFERENCES
}

Carter, P. G. \& Mallard, D. J. (1974). A study of the strength and density trends within the chalk of south-east England. Q. Jnl Engng Geol. 7 No. 1, 43-55.

Clayton, C. R. I. (1976). Private communication.

Dennehy, J. P. (1975). The misuse of SPT $N$ value correlations with Upper Chalk grades. Géotechnique 26, No. $1,217-220$.

Wakeling, T. R. M. (1969). A comparison of the results of standard site investigation methods against the results of a detailed geotechnical investigation in Middle Chalk at Mundford, Norfolk. Proc. Conf. in situ Investigations in Soils and Rocks, 17-22. London: British Geotechnical Society.

Ward, W. H. Burland, J. B. \& Gallois, R. W. (1968). Geotechnical assessment of a site at Mundford, Norfolk, for a proton accelerator. Géotechnique 18, No. 4, 399-431.

\section{Design manufacture and performance of a lateral strain device}

\author{
EL-RUWAYIH, A. A. (1976). Géotechnique 26, No. 1, 215-216.
}

\section{B. K. Menzies, University of Surrey}

I congratulate the Author and his colleagues on developing a device for measuring automatically lateral deformation in the triaxial test. The accurate measurement of lateral strain in uniaxial and triaxial test specimens of soil or rock enables Poisson's ratio to be estimated and is of crucial importance in the calculation of the vertical principal stress difference. A direct measurement of the change in diameter of the deforming middle portion of a test specimen obviates the necessity for applying an area correction based on assumptions about the specimen's change in volume or change in shape, or both.

A lateral strain caliper for automatically measuring the change in diameter of uniaxial and triaxial test specimens has been developed at the University of Surrey and is shown in Fig. 1. It consists of a circular caliper cut from clear acrylic polymer plate. The hinge of the caliper is secured by a stainless steel pin bushed in PTFE. Diametrically opposite the hinge the caliper opening is bridged by a miniature water-submersible displacement transducer of the inductance type. The body of the transducer is partly housed in a block pivoting in the horizontal plane of the caliper on a PTFE-capped hollow stainless steel post fixed on one arm of the caliper. The armature of the transducer is similarly secured on the other arm of the caliper. Both the transducer body and transducer armature are thus free to maintain co-axial alignment of the coupled transducer during opening and closing the caliper. The caliper is 


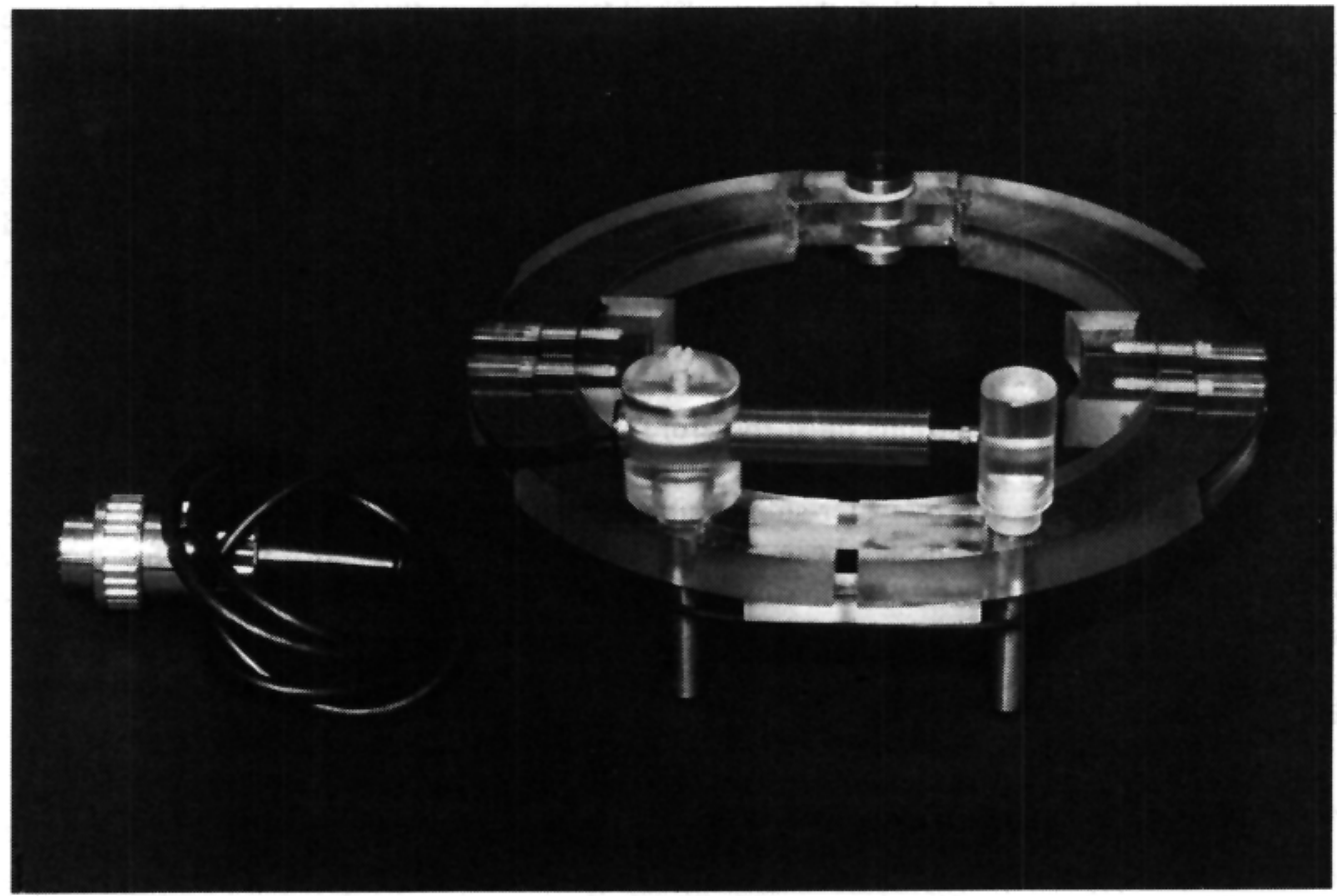

Fig. 1. Lateral strain caliper for uniaxial and triaxial test specimens

constrained in the closed position by a soft rubber O-ring stretched between the post carrying the transducer body and the post carrying the transducer armature. The transducer lead passes through an O-ring seal in the triaxial cell base.

The caliper is positioned around the middle of the test specimen which is lightly held by two curved pads fixed on the inside of the caliper. Flat pads may be used for prismatic test specimens. The pads are located on opposite ends of the diameter normal to that passing through the hinge. Any change in diameter of the test specimen causes a corresponding amplified change in the caliper opening which is continuously measured by the transducer. The relationship between the change in test specimen diameter and transducer output is linear. The resolution of the caliper depends largely on the sensitivity of indication of the transducer output. On monitoring $100 \mathrm{~mm}$ diameter test specimens on a three-figure indicator spanning the full range of the transducer, lateral strains of the order of $0.005 \%$ may be discerned.

The caliper shown in Fig. 1 has been used to monitor lateral strains of $76 \mathrm{~mm}$ diameter chalk marl triaxial test specimens turned from core samples obtained from marine borings in the English Channel. With the range of the transducer adjusted to span anticipated deformations, displacements of $0.003 \mathrm{~mm}$ were read on a three-figure recorder. Greater sensitivity is possible but then calibration becomes increasingly difficult. The submerged or dry caliper may be calibrated on a series of accurately measured steps turned on a stainless metal cylinder. For triaxial tests the caliper may be made neutrally buoyant by incorporating flotation chambers.

The caliper may be used to facilitate $K_{0}$ consolidation in the conventional triaxial cell by maintaining the transducer output within limits by varying the cell pressure, either manually 
or automatically, thus simulating the zero lateral strain condition. Attempts to restore sampled specimens to their in situ stresses prior to testing may therefore be realistically made.

The uses of the lateral strain caliper may be extended to facilitate the carrying out of appropriate measurements of axial strain during uniaxial and triaxial tests.

The frictional restraint of the end platens causes the specimen to deform under axial loading in the characteristically 'barrelled' fashion, deformation being concentrated in the middle third of the specimen. To base axial strain measurements on the displacement of the top platen gives an under-estimate of the true axial strain (Arthur and Menzies, 1968) and therefore an over-estimate of the Young's modulus. Even using lubricated platens (Rowe and Barden, 1965) does not preclude the possibility of local strains exceeding the integrated value (Arthur and Phillips, 1972). Axial strains must therefore be measured locally.

This may be done by using two or more lateral strain calipers separated by a small gauge length and bridged vertically by water-submersible displacement transducers of the inductance type. A similar arrangement has been described by Brown and Snaith (1974) for triaxial compression test specimens of bituminous road base material tested in a cell fluid of transformer oil or air.

\section{REFERENCES}

Arthur, J. R. F. \& Menzies, B. K. (1968). Correspondence: A new soil testing apparatus. Géotechnique 18, No. 2, 271-272.

Arthur, J. R. F. \& Phillips, A. B. (1972). Discussion: Inherent anisotropy in a sand. Géotechnique 22, No. 3, 537-538.

Brown, S. F. \& Snaith, M. S. (1974). The measurement of recoverable and irrecoverable deformations on the repeated load triaxial test. Géotechnique 24, No. 2, 255-259.

Rowe, P. W. \& Barden, L. (1965). Closure to discussion on: Importance of free-ends in triaxial testing. Jnl Soil Mech. Fdn Div. Am. Soc. Civ. Engrs 91, 105-106. 